\title{
ARTIFICIAL NESTING PLATFORMS FOR FERRUGINOUS HAWKS
}

C. STUART HOUSTON, 863 University Drive, Saskatoon, Saskatchewan S7N OJE

The Ferruginous Hawk, our largest buteo, now occupies a much smaller range in smaller numbers than it did in the early days of settlement. A beautiful and beneficial "gopher hawk," it was once the dominant buteo over the grasslands and over that area kept largely free of trees by prairie fires now known as "parkland." In Saskatchewan, with the ploughing of more and more grassland and conversion to grain crops, the Ferruginous Hawk has persisted mainly in the southern and western parts of the province where there are large government pastures with substantial areas of grassland. ${ }^{15}$ It has disappeared from Manitoba. ${ }^{2}$ My studies indicate that each pair requires about $2 \mathrm{sq}$ mi of pasture. The pasture must have a high concentration of Richardson's ground squirrels, the main food source of both the Ferruginous and Swainson's Hawks. ${ }^{7}$ Unless there are steep hills or cliffs or large stone piles, these pastures must also contain trees for nesting sites. In flat country we have found no nests on pastures that had no trees, though Ferruginous Hawks are known to nest on the ground in flat terrain as well as badlands in South Dakota. ${ }^{4} 6$

Since 1969 my banding efforts have centered on a 24.5-square-mile pasture near Kindersley, Saskatchewan. Fortunately, Hubert Solverson, the pasture manager from 1960 until this year, kept a watchful, friendly eye on the hawks. No gopher poison was used during his tenure, in spite of pressure to do so from farmers using the pasture. Solverson preferred to rely on the natural gophercatching abilities of the resident buteos.

The most successful Ferruginous site has been a lone tree near the northeast corner of the pasture. Glen A. Fox (pers comm.) visited this nest on 15 May 1960 when it contained three eggs; the pair subsequently deserted and the nest was empty on 24 June. Solverson reports that young were successfully fledged from this nest each year from 1961 through 1968, and I banded young each year from 1969 through 1982, a total of 22 consecutive successful years. We do not know how often the adults have changed, but since 1969 there has been one melanistic and one lightphase adult. The only close call was in 1973, when the nest had fallen from the tree a few days before our visit on 23 June. Two of the four young had been crushed beneath the fallen nest, one had been trampled by cattle, and the survivor was banded and replaced in an improved remnant of the nest in the tree. In the 14 years that I have visited this single nest, 50 young have been raised. This must be an unusually good territory and these hawks must be exceptionally good hunters.

We became concerned about how long this, the only tree for more than a mile in any direction, might survive. Its roots are exposed by multitudes of cattle rubbing against the tree and trampling a depression around its base (Fig. 1). We watched as other trees in deserted, deteriorating and uncared-for shelter belts containing heavy Ferruginous nests were similarly weakened by cattle and blew over in high winds (Fig. 2). These trees are a great attraction to the cattle who use them for rubbing and for shade. We thought of placing rock piles at the base of each nest tree, but Solverson vetoed this idea, as a potential hazard to the cattle, who might break their legs. We considered fencing the 


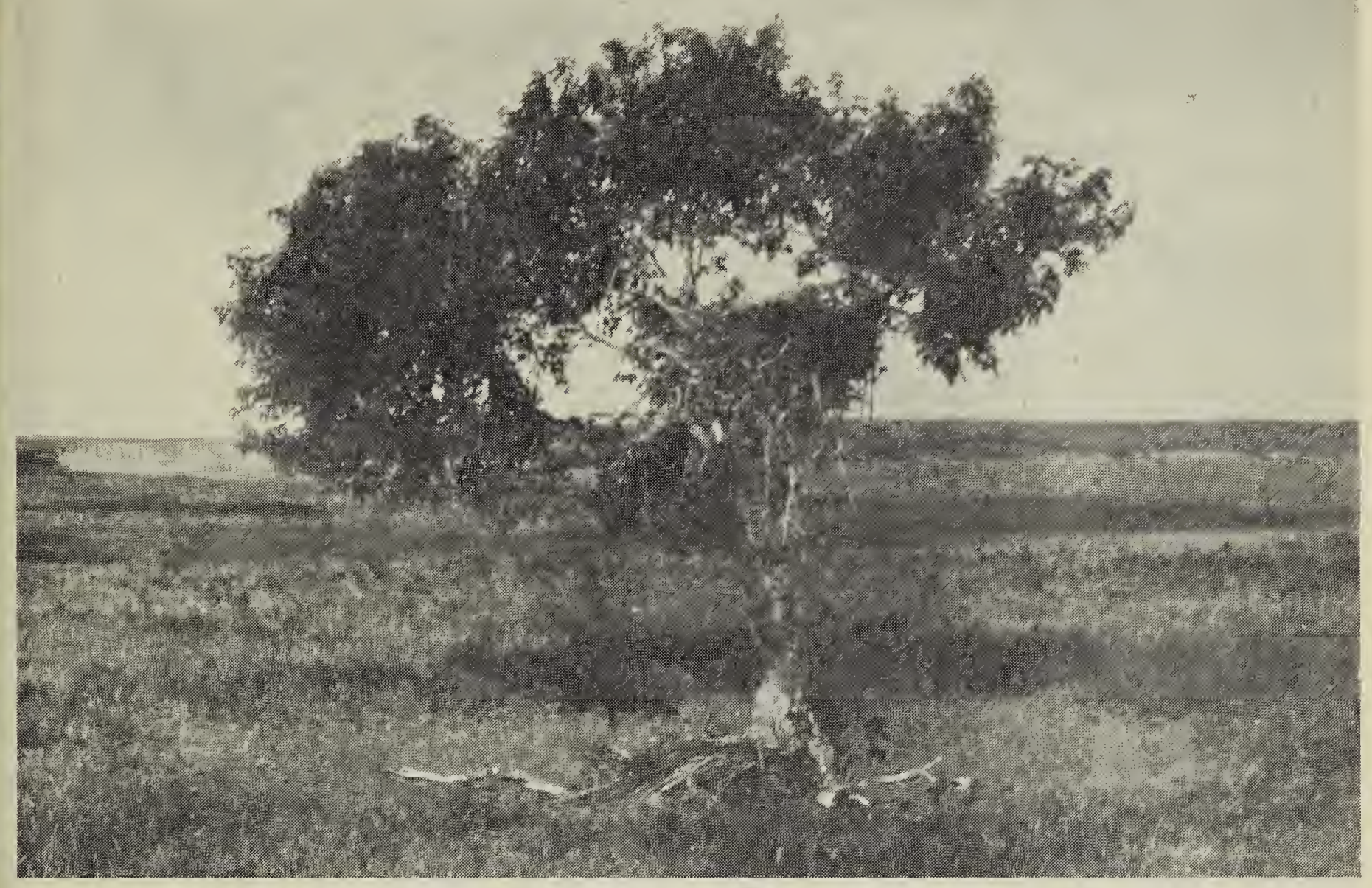

Fig. 1 Solitary maple tree with successful Ferruginous nesting for 22 consecutive years. C. S. Houston

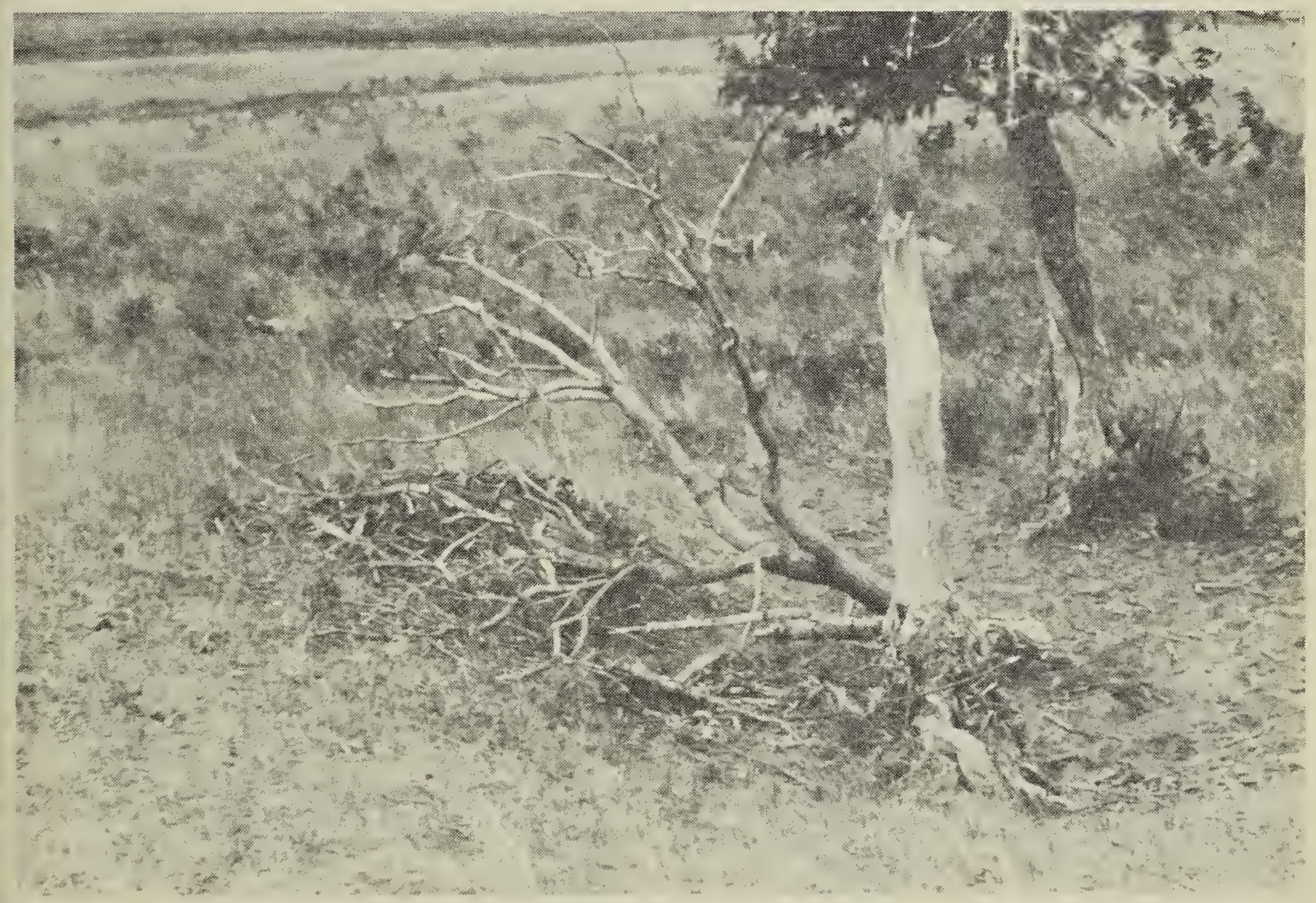

Fig. 2 Broken tree with Ferruginous nest on ground. Failed nesting for that year

C. S. Houston 
remaining shelter belts on the pasture, but Solverson wished the cattle to have access to the shelter and shade they provided.

I then enlisted the help of Keith and Jean Harris in providing the best of the remaining solutions - nesting platforms. On 28 October 1972, in a snowstorm, Keith, Jean, Mary and I put up the first six experimental nest platforms. Keith had persuaded the Saskatchewan Power Corporation to donate the poles, which he cut in half. He also supplied at no charge two trucks, a long trailer to carry the poles, and a backhoe. At each site, Keith dug a hole nearly six feet deep, then we placed the pole upright and pushed in dirt around it. Keith lifted me up in the backhoe bucket to hammer on the platform in solid safety. Since this was an experiment, we placed large tractor tires on two poles, and filled them with sticks. On two others, we placed the bottoms of large oil drums (Fig. 3). On the final two, we placed shallow wooden boxes, each 30 inches square. Each was the right height

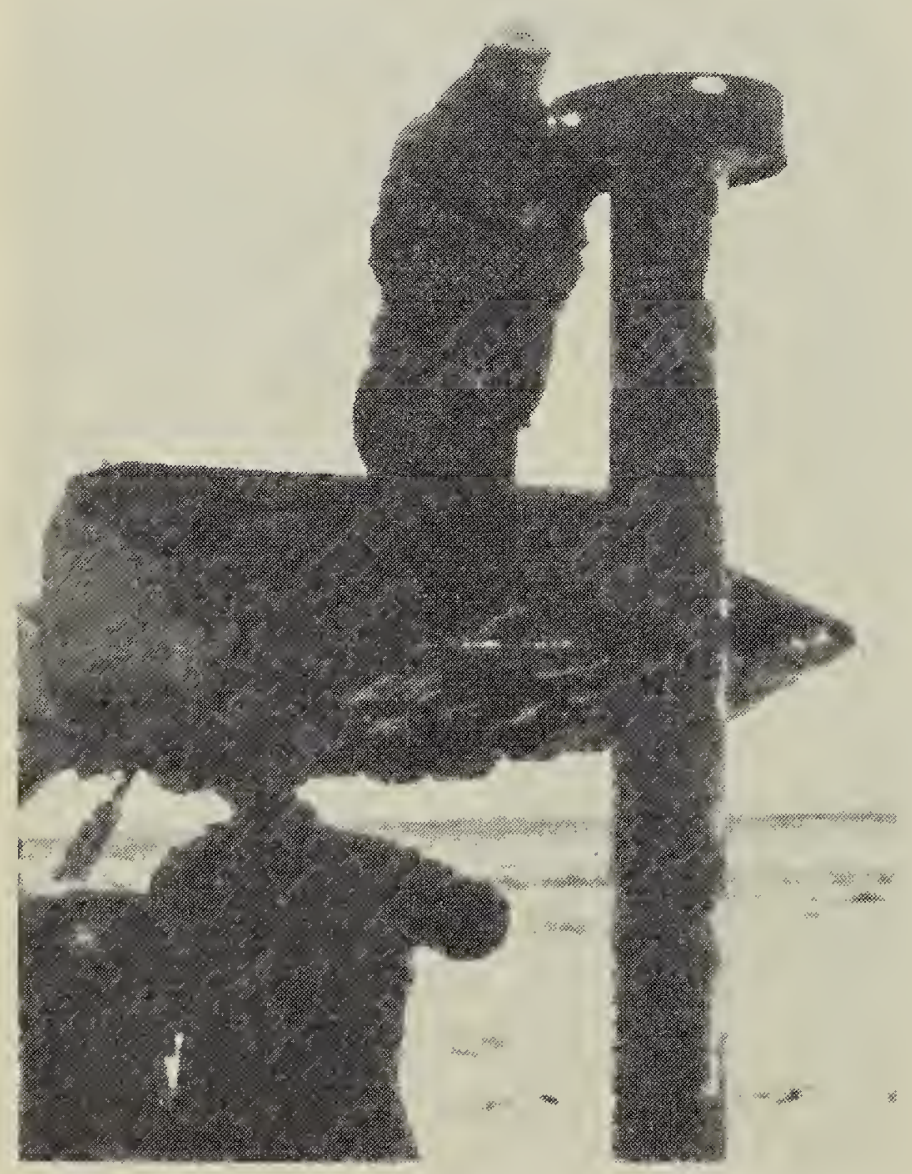

Fig. 3 Placing of unsuccessful oil drum platform.

C. S. Houston for banding and photography purposes, being five feet above the roof of my 4-wheel-drive vehicle (Fig. 4).

In 1973 our June visit was a disappointment. No hawks had used the poles. In 1974 and 1975, Hubert Solverson reported that a pair of hawks had taken up residence on pole No. 3 , but both years they had deserted by the time of our visit in mid-J une. However, the same pole, with a wooden box, was used successfully by a pair of Ferruginous Hawks in 1976 and we banded three young on 19 June. Although our sample was too small to prove that wooden boxes were preferred, we decided that in spite of the sticks separating the metal of the drums and the rubber of the tires from the center of the nest, that perhaps the metal and rubber became too hot in the mid-day sun. On 24 October 1976 Gerhard Stuewe, Bruce Donovan and I went out and replaced the tires and oil drums, substituting four more shallow wooden boxes.

We were pretty excited in 1977, the first nesting season following our changeover, to find three of the six boxes in use by Ferruginous Hawks, which raised three, three and one young, on poles 2, 3 and 5 . This did not prove to be as good an omen as it seemed, for 1977 was the only year with three successful nests. In 1978, a Ferruginous Hawk raised three young on pole 2 and a Swainson's Hawk raised two young on pole 5 . In 1979, four poles were occupied at our first visit, but the Swainson's Hawks on poles 3 and 5 were both unsuccessful, while Ferruginous pairs raised three and four young respectively on poles 2 and 4 . Poles 2 and 4 continued in use by Ferruginous Hawks, and raised two and three young in 1980 and two and four young in 1981. In 1982, all previously used boxes were unoccupied for reasons unknown to us, but pole 1 was used for the first time by a pair of Swainson's Hawks that were still incubating an addled egg on 25 July. 


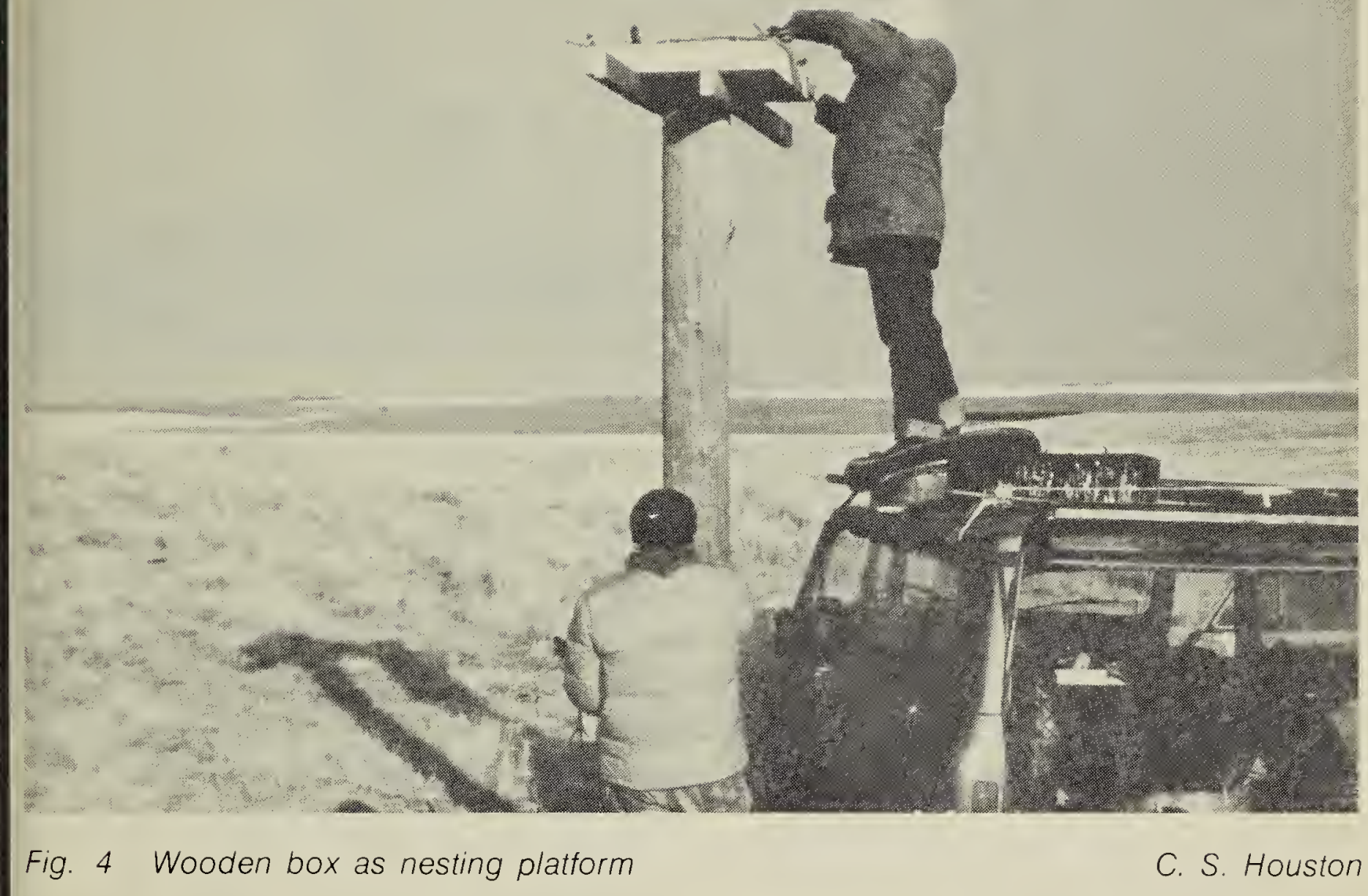

Fig. 4 Wooden box as nesting platform

C. S. Houston
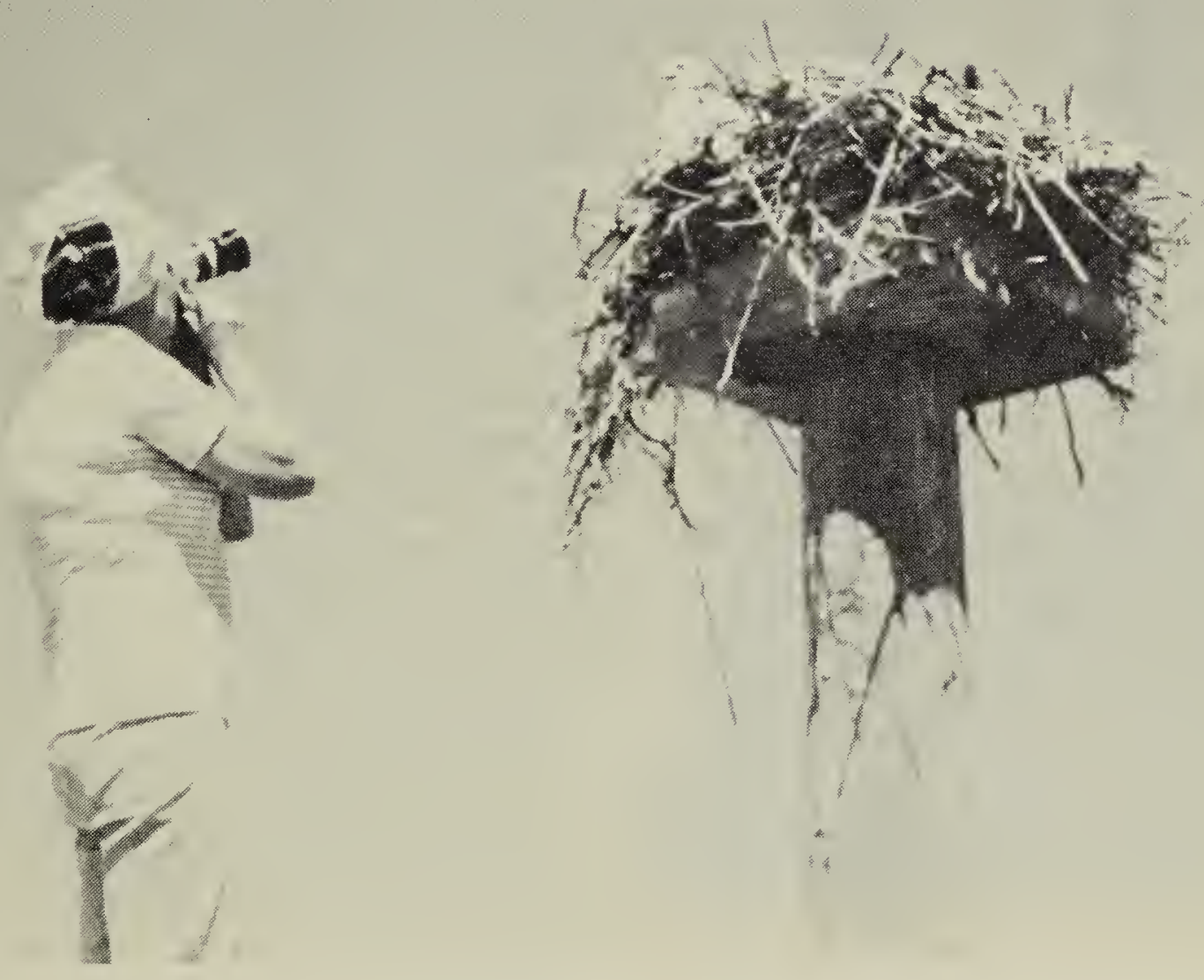

Fig. 5 Jean Harris, on roof of vehicle, photographing young Ferruginous Hawks on nest platform.

C. S. Houston 
In all, 26 young Ferruginous Hawks have been fledged from our pole nests in 11 nestings, only two nesting attempts were unsuccessful, both of these in the first two years (Figs. 5, 6, 7). Only two Swainson's Hawks have fledged from four nesting attempts. Five of the six poles have been occupied at least once. The sixth is within the territory of the lone tree mentioned above, and is in readiness for the year that the tree topples over.

On 12 September 1982 Keith and Jean again placed about $\$ 200,000$ worth of equipment at our disposal, and donated their services for the day. Each drove one truck. Keith had purchased a dozen telephone poles for $\$ 6$ each. The Saskatchewan Natural History Society paid for the lumber, which was cut in advance by Dick Ehman and the boxes were built by Kelly Wylie, Doug and

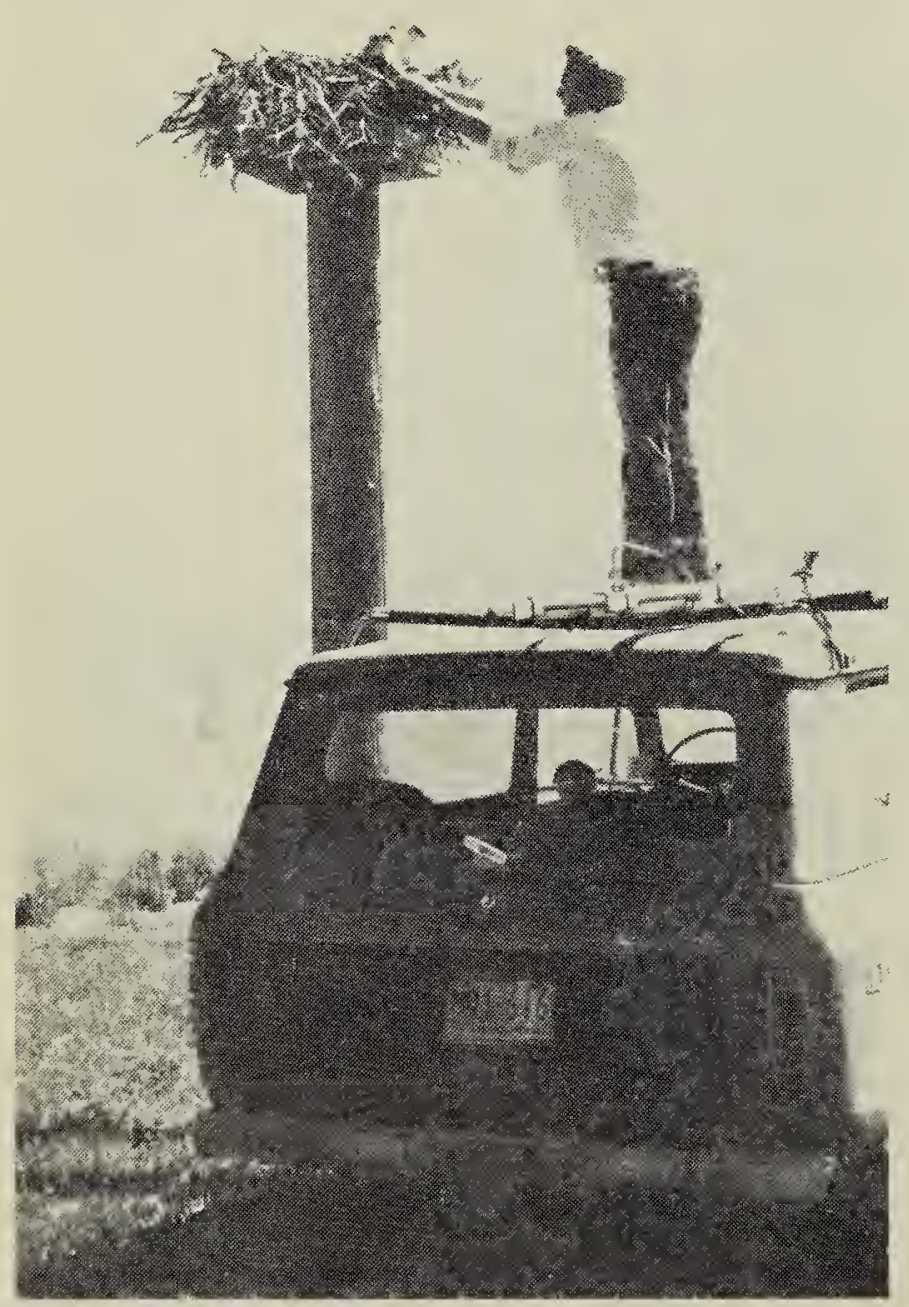

Fig. 6 Stuart Houston banding young Ferruginous Hawks from roof of vehicle. Jean M. Harris

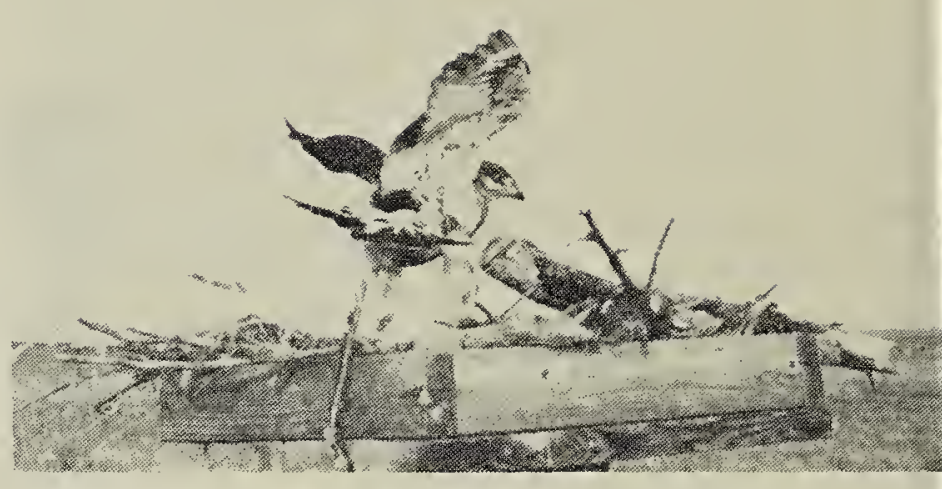

Fig. 7 Young Ferruginous Hawks on nest platform, ready to fledge. C. S. Houston

Cathy Tomlinson. The Saskatoon contingent of Kelly Wylie as master carpenter for the occasion, Nigel Caulkett, Alan R. Smith and Cathy Tomlinson left with me at 6:30 a.m. With permission of pasture manager Ed Melchior we placed three poles at 1-mi intervals on the 18-sq-mi east block of a pasture that has no trees at all. Ferruginous Hawks have nested successfully for years in trees just outside the southeast corner of this pasture. Each of the boxes was filled with sticks, a central depression was made for the nest, and the sides were ornamented with cow-dung - in nature the sure-fire sign of Ferruginous occupancy. We placed another three poles in the 14.5sq-mi west block of this pasture, which has only one or two clumps of trees in a coulee. After Jean served us a delicious beef supper, we placed the last two poles in the smaller treeless extremities of a 5-sq-mi pasture not far from the Harris' rural home.

The 1972 experiment has been a success. It is small in comparison with the Canadian Wildlife Service project near Brooks, Alberta, under the direction of Richard W. Fyfe. They placed 98 poles on pastures and of these about 16 have been used (Alan R. Smith, and J.K. Schmutz, pers. comm.). Ferruginous Hawks are accustomed to nesting in exposed positions on hillsides and the lack of shade seems not to be a 
ig. 8 Pole with nest platform - visia of open pasture.

Jean M. Harris etriment, although Keith Harris built ne nest platform this year with slat ides to provide some shade.

Our success is especially impressive ecause the poles were added to a asture that already had an incredibly igh density of four to six pairs of erruginous Hawks, a ratio of 1 pair per .1 to $6.1 \mathrm{sq} \mathrm{mi}$ or 10.6 to $15.9 \mathrm{~km}^{2}$, aparently the highest density recorded nywhere. Lokemoen and. Duebbert lad one pair per $17.4 \mathrm{~km}^{2}$ on their study rea of prime habitat in South Dakota. ${ }^{6}$ With the addition of nesting platforms in he treeless portions of this pasture, hree pairs used poles in 1977 and the umber of pairs increased to nine, all uccessful, a ratio of one pair to $2.7 \mathrm{sq}$ ni or $7.1 \mathrm{~km}^{2}$.

It is fortunate indeed that Keith Harris wns and operates an oil well service ompany that has the equipment we eed. It is even more fortunate that Jean s a dedicated bird watcher who has een finding hawk nests for me for 13 ears and a photographer who has won umerous prizes in competitions. In 982 Jean located 41 nesting pairs of wainson's Hawks in her area, and I anded 50 young in the 24 nests that ere successful.

The equipment provided by Keith rould rent for $\$ 92$ an hour. If he was reimbursed, total costs would be in the neighborhood of $\$ 100$ for each nest platform. This is roughly the same as the $\$ 113$ estimated for similar platforms in Alberta by Richard Fyfe. ${ }^{3}$

To prevent a further decline in Ferruginous Hawk numbers in years to come, retention of habitat is of first importance and we must preserve as much pasture as possible. We must also ensure that nesting sites are available. When these are lacking, nest platforms offer a suitable alternative to natural trees.

ARCHIBOLD, O.W., and M. R. WILSON. 1980. The natural vegetation of Saskatchewan prior to agricultural settlement. Canadian Journal of Botany 58:20312042.

BECHARD, M. J. 1981. Historical nest records for the Ferruginous Hawk in Manitoba. Canadian Field-Naturalist 95:467-468.

${ }^{3}$ BRIDGES, J. M. 1980. Raptor nesting platforms and the need for further studies. Presented at a workshop on raptors and energy developments at Boise, Idaho, Reading: Gilbert-Commonwealth Engineers-Consultants, $5 \mathrm{pp}$.

${ }^{4}$ BLAIR, C. L., and F. SCHITOSKEY, Jr. 1982. Breeding biology and diet of the Ferruginous Hawk in South Dakota. Wilson Bulletin 94:46-54.

${ }^{5}$ HOUSTON, C. S. 1977. Changing patterns of Corvidae on the Prairies. Blue Jay 35: 149-155.

${ }^{6}$ LOKEMOEN, J. H., and H. J. DUEBBERT. 1976. Ferruginous Hawk nesting ecology and raptor populations in northern South Dakota. Condor 78:464470.

SCHMUTZ, J.K., S.M. SCHMUTZ, and D. A. BOAG. 1980. Coexistence of three species of hawks (Buteo spp.) in the prairie-parkland ecotone. Canadian Journal of Zoology 58:1075-1089.

${ }^{8}$ SNOW, C. 1974. Habitat management series for unique or endangered species No. 13. Ferruginous Hawk, Buteo regalis. Technical Note. Denver: U.S. Department of Interior, Bureau of Land Management. 23 pp. 